\title{
FINANCIAL CRISIS AS A FACTOR OF IMPLEMENTATION OF DEVELOPMENT OF A NEW DIVERSIFIED BANKING SECTOR ON THE EXAMPLE OF BOSNIA AND HERZEGOVINA
}

Sonja Tomash-Miskin, Banja Luka School of Economics, Kralja Alfonsa XIII, Banja Luka 78000, Bosnia \& Herzegovina, sonjat984@gmail.com

\begin{abstract}
Since the end of 2008, there has been a crisis of economic proportions in the world, which can be treated as a financial crisis. It took on global proportions and shook the leading countries in terms of economic strength, which soon spread to the entire world economy. Leading economic analysts agree that the immediate driver of the economic crisis, which can be more precisely defined as the financial crisis, was the collapse of the subprime mortgage market in the United States, which quickly spread to other countries due to the openness of economies. This has led to interventions in the economies and economies of most countries that can be characterized as interventions of nation states, first in the financial and then the real sector. The goal of the interventions that national economies were supposed to establish in the economy was to stop the real declines in the economic activity of all legal entities in order to bring the effects of the activity closer to the realistically projected ones.
\end{abstract}

Keywords: financial crisis, 2008, intervention, globalization.

\section{INTRODUCTION}

The financial crisis, which began in the world with signs of great manifestation and impact on a large number of both highly developed countries in the world and on countries in transition, is tied to 2008. It had a distinct depth and covered a large number of developed economies, i.e. countries both the most developed and developing countries, i.e. transition countries.

The great economic crisis, that is, the financial crisis, has its manifestation to the greatest extent in transition countries such as Bosnia and Herzegovina. The consequences of the crisis largely affect the need for rapid changes that should be made primarily by the state through 
its governance apparatus in order to reduce the impact of negative phenomena in the national economy.

The financial crisis appeared in the most developed economy in the world at that time, the ratio in the USA during 2008 as a crisis related to the situation on the real estate market in the USA.

However, the impact of the crisis quickly spread to a large number of countries, and thus to transition countries such as Bosnia and Herzegovina.

The impact of the financial crisis has spread very quickly to a large number of economies in the world, and especially to countries affected by transition processes and economic reforms such as Bosnia and Herzegovina. In those countries, the need for state measures of influence was felt almost immediately, and without the help of the state, they would fall into unsolvable problems, and then a large number of companies could be shut down and a large number of jobs lost, i.e. high unemployment would occur.

In this paper, the author focuses on the usefulness of the impact of state interventionist measures on the management of the overall economy of a transition country such as Bosnia and Herzegovina, and similar experiences could be applied in other transition countries.

\section{EXPERIENCES OF AUTHORS IN THE LITERATURE BASED ON THE ANALYSIS OF THE FINANCIAL CRISIS IN THE WORLD DURING (2008)}

Numerous authors have written their views in the literature on the 2008 financial crisis. For example, [1] he pointed out at the beginning of the eighties of the last century that he laid the theoretical foundations for generating the crisis, and according to him, it appeared in 2008 [1], primarily as a mortgage crisis.

It has essentially grown into a financial crisis, with a large fluctuation in real estate prices. Banks were the focus of the crisis on that occasion because they gave mortgages on real estate. Some authors, such as [2], point out back in 2005, three years before the official financial crisis, that there is a possibility of inflating real estate price bubbles.

The third group of authors, led by [3], pointed out that there is a danger of the growth of the mortgage market, namely the rapid growth of the confused market. In addition, they pointed out that households that are in mortgage indebtedness will almost certainly lose their income at some point and fall into a debt crisis. At the same time, they pointed out that the goal of the economy is to avoid the domino effect of the financial crisis on the economy as a whole. 
The fourth group of authors [4] pointed out that there was a long-term bad policy in conducting state policy and its impact on the country's economy due to inadequate general policy of promoting housing loans.

The fifth group of authors [5] pointed out the existence of excessive self-confidence in conducting primarily the policy of the Government, which preceded the upcoming financial crisis.

\section{SITUATION BEFORE THE CRISIS IN 2008}

Investing in real estate in the years before the crisis seemed like a completely safe investment in the opinion of a large number of citizens, but also directors of large companies in the world. Contrary to them, there were authors like [6] who pointed out that there was excessive self-confidence in terms of form, formation of financial markets, credit expansion, rising prices and indebtedness, and exposing the whole economy to great risks.

The banking sector of Bosnia and Herzegovina suffered major blows during the crisis in 2008. 2008 is the official year of the financial crisis. Like other transition countries, it was only then that it began active measures to slow down the negative effects of the crisis on the country's general economy at the state level. Attempts have been made to do this by applying the decisions of regulatory state institutions, the measures of which could reduce the negativity of the financial crisis.

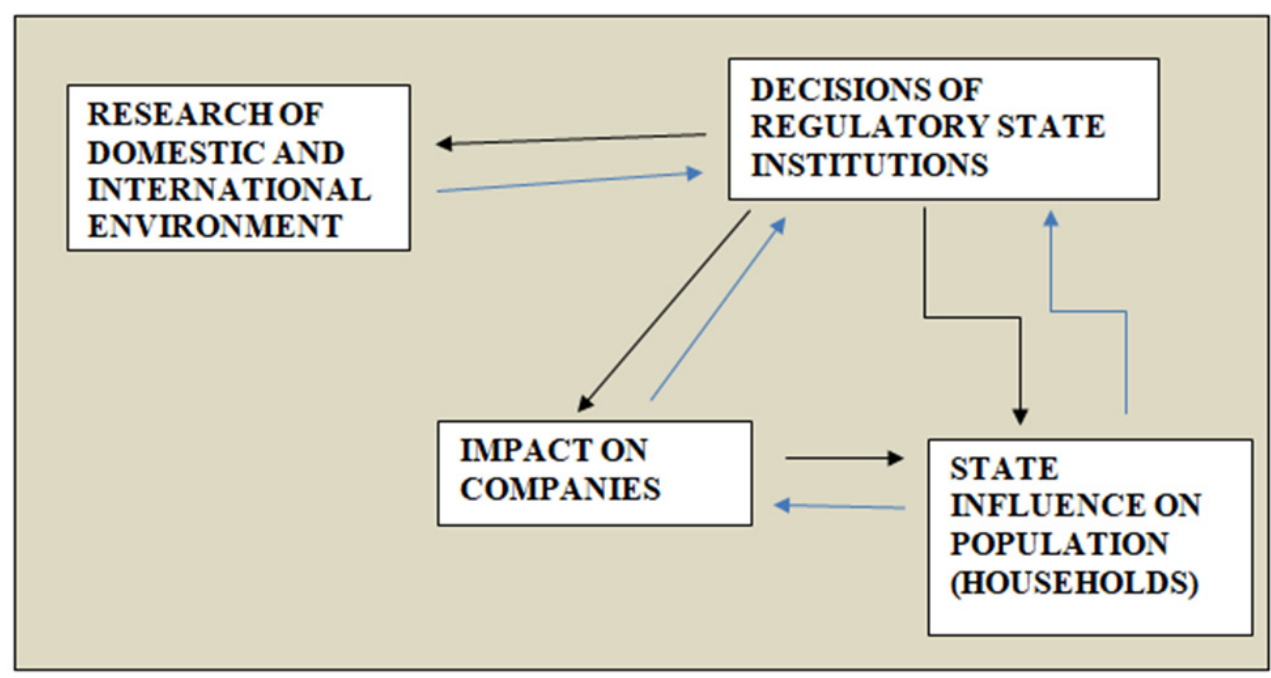

Fig. 1: Review of the impact of the environment on the adoption of state bodies and its impact on the economy and the population. 
The situation before the financial crisis can be shown using Figure 1, which shows the impact of the environment on government decisions, as well as the relationship of government agencies with the economy and citizens, which the author illustrates through Figure 1.

The development of the economy in countries in transition, and thus in Bosnia and Herzegovina, relies to a large extent on a very wide range of state policy measures that affect a number of heterogeneous legal entities [8-15]. In that way, the business of many companies can be directly influenced, which differ greatly in their characteristics. Substantial state influence is visible in very numerous and heterogeneous enterprises [16-20]. The goal of the measures taken is to ensure positive business in many companies in order for it to operate positively.

\section{ILLUSTRATING THE ORIGIN OF CAPITAL IN BOSNIA AND HERZEGOVINA IN TERMS OF THE SHARE OF FOUNDING CAPITAL IN THE COUNTRY'S BANKING SYSTEM}

In the continuation of the paper, the author gives an illustration of the origin of capital in banks in Bosnia and Herzegovina. The presentation is given in table number 1.

Table 1: Banks in Bosnia and Hercegovina, origin of founding capital, headquarters and shareholders, situation in 2020

\begin{tabular}{|c|c|c|c|c|}
\hline $\begin{array}{c}\text { Serial } \\
\text { number }\end{array}$ & Name of the bank & $\begin{array}{l}\text { Origin of the founding } \\
\text { capital }\end{array}$ & Headquarters & Shareholders \\
\hline 1 & Addiko Bank & Austria & Banja Luka & Addiko Bank \\
\hline 2 & Addiko Bank & Austria & Sarajevo & Addiko Bank \\
\hline 3 & ASA banka & Bosnia and Hercegovina & Sarajevo & \\
\hline 4 & Bosna Bank International & Saudi Arabia & Sarajevo & $\begin{array}{c}\text { Islamic Development } \\
\text { Bank }\end{array}$ \\
\hline 5 & Intesa Sanpaolo banka & Italy & Sarajevo & Intesa Sanpaolo \\
\hline 6 & Komercijalna banka & Serbia & Banja Luka & Komercijalna banka \\
\hline 7 & $\begin{array}{c}\text { Komercijalno-investiciona } \\
\text { banka }\end{array}$ & Bosnia and Hercegovina & Velika Kladuša & \\
\hline 8 & MF banka & Bosnia and Hercegovina & Banja Luka & \\
\hline 9 & Naša banka & Bosnia and Hercegovina & Bijeljina & \\
\hline
\end{tabular}




\begin{tabular}{|c|c|c|c|c|}
\hline 10 & NLB banka d.d. & Slovenia & Sarajevo & NLB Group \\
\hline 11 & NLB banka a.d. & Slovenia & Banja Luka & NLB Group \\
\hline 12 & Nova banka & Bosnia and Hercegovina & Banja Luka & \\
\hline 13 & Privredna banka Sarajevo & Bosnia and Hercegovina & Sarajevo & \\
\hline 14 & ProCredit Bank & Germany & Sarajevo & ProCredit Bank \\
\hline 15 & Raiffeisen Bank & Austria & Sarajevo & Raiffeisen Bank \\
\hline 16 & Sberbank a.d. & Slovenia & Banja Luka & Sberbank Europe \\
\hline 17 & Sberbank BH & Slovenia & Sarajevo & Sberbank Europe \\
\hline 18 & Sparkasse Bank & Austria & Sarajevo & Erste Group \\
\hline 19 & UniCredit Bank & Italy & Mostar & UniCredit \\
\hline 20 & Uni Credit Bank Banja Luka & Italy & Banja Luka & UniCredit \\
\hline 21 & Union banka & Bosnia and Hercegovina & Sarajevo & \\
\hline 22 & Vakufska banka & Bosnia and Hercegovina & Sarajevo & \\
\hline 23 & ZiraatBank BH & Turkey & Sarajevo & Ziraat Bank \\
\hline
\end{tabular}

Based on the presentation in Table 1, it is clear that in 23 banks there is a wide range of ownership that extends to several countries (more than 10), which makes a well-distributed regional investment in the banking structure of Bosnia and Herzegovina.

\section{CONCLUSIONS}

The formation of interventions by national governments in terms of increasing economic activity in most countries is a priority, especially in times of crisis. Anti-recession measures are increasingly being considered at the global level. For example, the countries that make up the $\mathrm{G}$ - 20 group try to impose measures on other countries in order to coordinate the overall world economic policy, but according to their success criteria, i.e. to submit to the rules of conduct of transition countries. In the conditions of a modern globalized economy, there is practically no national economy that would be immune to the influences of large and powerful economies that essentially pursue globalist politics where their primary goals are the ones they want to achieve. In essence, it should be pointed out that the consequences of the absence of a development strategy and irresponsible behaviour of the executive branch must be eliminated primarily by the state's intervention to solve the conditions of general business that will be favourable for most legal entities. This is of great importance in the 
conditions of the economic crisis which is defined as the financial crisis of the global level. Based on what is presented in the paper, it should be noted that transition countries such as Bosnia and Herzegovina should develop their own path in conducting economic policy in order to be able to help and act promptly to a large number of legal entities at a given time. This is of great importance especially in cases of financial and general economic crisis.

\section{REFERENCES}

[1] Minsky, H. (1982). Can „It“" Happen Again//ISBN 978-0-332213-3.

[2] Shiller, R. (2005). Irrational Exuberance, Princeton University Press.

[3] Gramlich, E. M. (2007). Subprime Mortgages: America's Latest Boom and Bust, The Urban Institute Press, Washington.

[4] Gennaioli, N. \& Shleifer, A. (2018). A Crisis of Beliefs: Investor Psychology and Financial Fragility, Princeton University Press.

[5] Gorton, G. B. (2010). Slapped by the Invisible Hand: The Panic of 2007, Oxford University Press.

[6] Gorton, G. B. (2012). Misunderstanding Financial Crises - Why We Don't See Them Coming, Oxford University Press.

[7] Šoškić, D. (2009). Globalna finansijska kriza i Srbija: pouke i mjere//Svjetska ekonomska kriza i Ekonomska politika Srbije u 2009.godini, Ekonomski fakultet Beograd,Beograd.

[8] Sonja Tomaš-Miskin (2021). Doktorska disertacija, Strategijsko upravljanje performansama banaka Bosne i Hercegovine u uslovima finansijske krize, Univerzitet Union Beograd, Beogradska Bankarska Akdemija, Fakultet za bankarstvo, osiguranje i finansije.

[9] Popović, S., Novaković, S., Đuranović, D., Mijić, R., Grublješić, Ž, Aničić, J., Majstorović, A. (2017). Application of international accounting standard-16 in a public company with predominantly agricultural activities, Economic Research-Ekonomska Istraživanja, 30(1): 1850-1864.

[10] Popović, S. (2014). Socio-ekonomski faktori ograničenja razvoja agrara, Monografija, Fimek, Novi Sad, Srbija.

[11] Popović, S., Ugrinović, M., Tomašević, S. (2015). Upravljanje menadžmenta poljoprivrednog preduzeća preko praćenja ukupnih troškova održavanja traktora, Poljoprivredna tehnika, 2: 101-106. 
[12] Popović, S., Ugrinović, M., Tomašević, S. (2015). Management of Agricultural Enterprises by Means of Fair Financial Reporting in Accordance with International Standards of the Finance and Accounting Reporting, CDQM, Number 3: 24-30.

[13] Popović, S., Mijić, R., Grublješić, Ž. (2014). Interna kontrola i interna revizija u funkciji menadžmenta. Škola Biznisa, 1, 95-107.

[14] Popović, S., Tošković, J., Majstorović, A., Brkanlić, S., Katić, A. (2015). The importance of continuous audit of financial statements of the company of countries joining the EU, Annals of the „Constantin Brâncuşi”" University of Târgu Jiu, Economy Series, Special Issue, 241-246.

[15] Bojović, R., Popović, V., Ikanović, J., Živanović, Lj., Rakaščan, N., Popović, S., Ugrenović, V \& Simić, D. (2019). Morphological characterization of sweet sorghum genotypes acrossen vironments, The J. Anim. Plant Sci. 29(3).

[16] Popović, S. (2015). Implementacija heterogenih rizika u radu interne revizije, Revizor 69. [17] Vitomir, J., Tomaš-Miskin, S., Ivić, M., Popović, S. (2020). Implementation of the Tender by the Municipal Service Administration from the Aspect of Management in the Municipalities of the Republic of Serbia, Lex Localis - Journal of Local Self-Government, 8, 3: $469-486$.

[18] Radović, M., Vitomir, J. and Popović, S. (2019). The Importance of Implementation of Internal Audit in Enterprises Founded by the Republic of Serbia, Lex Localis - Journal of Local Self-Government, 17, 4: 1001-1011.

[19] Bjelica, B., Bakmaz, O., Mijić, R., Popović, S. and Popović, V. (2017). The implementation of heterogeneous risk to the company's operations and transition countries respecting the behavior of agricultural enterprises in the republic of Serbia. Annals, Economy Series, 3 .

[20] Radović, M., Vitomir, J. \& Popović, S. (2021). Impact of internal control in enterprises founded by local self-government units: the case of Republic of Serbia, Inzinerine Ekonomika-Engineering Economics, 32(1): 82-90. 